Received 16.05.2017 Reviewed 16.06.2017 Accepted 26.06.2017

A - study design

B - data collection

C - statistical analysis

D - data interpretation

E - manuscript preparation

F - literature search

\section{Farmers' participation in Water User Association in western Iran}

Saeed GHOLAMREZAI ${ }^{\mathrm{DEF} \bowtie}$, Fatemeh SEPAHVAND ${ }^{\text {ABC }}$

Lorestan University, Department of Rural Development, Khorramabad-Boroujerd Road, Khorramabad, Lorestan Province, Iran; e-mail: gholamrezai.s@lu.ac.ir, sgholamrezai@gmail.com, sepahvandfatemeh1365a@gmail.com

For citation: Gholamrezai S., Sepahvand F. 2017. Farmers' participation in Water User Association in western Iran. Journal of Water and Land Development. No. 35 p. 49-56. DOI: 10.1515/jwld-2017-0067.

\begin{abstract}
One of the main challenges of water scarcity is the water consumption in the agriculture sector. Therefore, optimizing water consumption and applying an optimal management in the agriculture sector is necessary. The implementation of a participatory management of water resources in the rural areas and the creation of Water User Association (WUA) can be a successful approach towards this management. That requires the continuity of the management, the comprehensive participation of farmers, and the exploitation of water resources; however, this action needs to understand the factors affecting the behavior of consumers. Thus identifying the factors influencing farmers' intentions towards participation in WUA is essential. The purpose of this study is to identify factors affecting farmers' intentions towards participation in water user association, by theory of planned behavior (TPB). There are 21 agriculture water pumping stations active in Lorestan Province. Farmers at each agriculture water pumping stations make up a Water User Association. The population of this study consisted of all WUAs in western Iran $(N=1990)$, and through a proportional stratified random sampling technique farmers were selected $(N=133)$ from the population. Moreover, the validity of the questionnaire was confirmed by a panel of experts. The reliability of the questionnaire was calculated at pre-test stage for different parts of the questionnaire ranging from 0.83 until 0.91. The collected data were analyzed using Statistical Package for the Social Sciences 20 software. The results revealed that there were effective variables including subjective norm, attitude, and extension training courses which contributed to the importance of participation in the water management, and that the educational level of farmer was a controlled variable that could affect farmers' attitudes towards participating in Water User Association; these factors could explain 53\% of farmers' participation totally.
\end{abstract}

Key words: intensions, Iran, theory of planned behavior (TPB), water resources management, Water User Association (WUA)

\section{INTRODUCTION}

Water plays a crucial role in human life and agriculture. However, water resources are becoming scarcer around the world, imposing a problem for development of agriculture sector that needs more water resources. About $2 / 3$ of irrigated farms are located in developing countries, where irrigated farming is the main source of producing food. However, the average irrigation efficiency in these countries is only $38 \%$. This means that despite the limitation and unsuitable distribution of water resources, unfortunately the effi- ciency of using water is at low level [AFSHAR, ZARAFSHANI 2010]. One of the main problems inflicting countries in arid and semi-arid areas is the insufficiency of water for different uses like drinking, industrial, and agriculture use.

Water is one of the most important factors in human life. Its absolute limitation as a renewable resource and its excessive consumption due to population growth has resulted in a major worldwide crisis [NEJAT POUR 2008; TOHIDYAN FAR, REZAEI MOGHADDAM 2015]. In the past two decades, particularly during the last years of the $20^{\text {th }}$ century, water man- 
agement has become an international concern. It is said that economic growth (especially in the agricultural sector), society health promotions, meeting basic needs, sustainability of water resources and environmental conservation depend upon the proper management of water resources more than ever before [AGHAPOUR SABBAGHI 2009].

According to Iran's Energy Ministry, per capita renewable water resources declined from $13,000 \mathrm{~m}^{3}$ in 1921 to $1,400 \mathrm{~m}^{3}$ in 2014 . The situation is expected to worsen in the near future if the current trend prevails. Iran is among the countries which are expected to face water scarcity by 2025 . In low- and middle-income countries, agriculture and industrial sectors use $80 \%$ and $10 \%$ of water resources, respectively. However, in rich countries, as much as $60 \%$ of total water is used for farming and $30 \%$ for industrial purposes. The remaining $10 \%$ is used for drinking. In Iran, $92 \%$ of the total water resources are consumed for irrigating farmlands. Industries account for $2 \%$ of water consumed nationwide, while $6 \%$ is used for drinking [Iran Daily 2015]. Furthermore, out of the average rainfall volume of $376 \mathrm{~km}^{3} \cdot \mathrm{year}^{-1}$, an estimated $66 \%$ evaporates before reaching the rivers. The total longterm total renewable water resources are estimated at $137.5 \mathrm{~km}^{3}$ of which about $9 \mathrm{~km}^{3} \cdot$ year $^{-1}$ are external water resources. Internal renewable water resources are estimated at $128.5 \mathrm{~km}^{3} \cdot \mathrm{year}^{-1}$. Surface runoff represents a total of $97.3 \mathrm{~km}^{3} \cdot \mathrm{year}^{-1}$, of which 5.4 $\mathrm{km}^{3} \cdot \mathrm{year}^{-1}$ come from drainage of the aquifers, and groundwater recharge is estimated at about 49.3 $\mathrm{km}^{3}$ year ${ }^{-1}$, of which $12.7 \mathrm{~km}^{3} \cdot$ year $^{-1}$ are obtained from infiltration in the river bed, giving an overlap of $18.1 \mathrm{~km}^{3} \cdot$ year $^{-1}$ [FAO 2008].

So far, several methods have been expressed according to the situation for water resources management but the results show that paying attention only to the water projects without any regards to the participation of villagers has led efficiency and productivity of the performance of irrigation systems be much less than predicted in the planning and feasibility studies of water projects. Therefore, the efficiency of the water has been reduced to about 25 to $30 \%$ and investment in water resources development has faced decreasing returns.

Hence, the tendency has been created in managers and planners because of which besides using the management, the role of direct farmers and beneficiaries from water resources should be especially considered in the planning. The results of many studies have shown that low efficiency of water resources is leading to water loss that is due to operators being far from the water management [AFSHAR, ZARAFSHANI 2008]. In this context, a number of studies have also indicated that there is considerable economic harvesting in rural water supply schemes the main reason of which is to justify the farmers and their cooperation in the implementation process [HAYATI et al. 2010]. Therefore, general cooperation can play a key role for improving the management of natural resources as well as the efficiency of water harvesting [JINGLING et al. 2010].

The aim of establishing WUAs is to create the necessary situations for farmers to participate in the decision making process for efficient management of water resources [AFSHAR, ZARAFSHANI 2010]. These associations are established based on organizing the users within a legal framework so that they might control the construction, development, reconstruction, and maintenance of irrigation channels [SHABANALI FAMI et al. 2008]. On the one hand, individual's behavior is heavily influenced by their tendency. On the other hand, an individual's tendency towards participatory behavior depends on certain prerequisites [TAQIPOUR et al. 2015]. Therefore, the analysis of farmers' behavior under various circumstances becomes highly important [AFSHAR, ZARAFSHANI 2010]. Although establishing WUAs plays a very important role in different countries [BERGER et al. 2007; HUANG et al. 2010; KAZBEKOV et al. 2009; QIAO et al. 2009; UYSAL, ATIS 2010], we have little knowledge how it applies in Iran. To fill this gap, we have focused on of the Southwest provinces of Iran. According to importance of WUAs in water management and necessity of farmer participation in planning, implementation, and stability of this institute, any action to strengthen rural participation can be effective in sustainable water resources management [TAQIPOUR et al. 2015].

\section{THEORETICAL BACKGROUND}

Theory of planned behavior (TPB). One of the most thoroughly tested social cognitive models is Ajzen's Theory of Planned Behavior (TPB) [ARMITAGe, Conner 2001; Boudreau, Godin 2009]. The theory of planned behavior (TPB), originally proposed in 1985 by Icek Ajzen, is an extension of the theory of reasoned action (TRA) [AJZEN, FISHBEIN 1980; FISHBEIN, AJZEN 1975]. TPB is a theoretically structured framework that predicts and explains human behavior according to beliefs and attitudes [AJZEN 1991], TPB postulates that the proximal determinant of behavior is a personal attitude to perform the behavior, when three conceptually independent constructs determine attitude: attitude, subjective norm, and perceived behavioral control.

They are the specific salient beliefs which underlie behavioral, normative, and control beliefs determine all of the constructs (attitude, subjective norm, and perceived behavioral control. In addition, each of the TPB variables is defined by a set of salient beliefs. These three sets of beliefs are behavioral beliefs (attitude toward the behavior), normative beliefs (subjective norm), and control beliefs (perceived behavioral control).

\section{Attitude}

Attitude towards behavior and behavioral beliefs, the first important determinant for behavioral attitude, is attitude which refers to "the degree to which a per- 
son has a favorable or unfavorable evaluation or appraisal of the behavior in question" [AJZEN 1991; KIM et al. 2013]. In other words, a person's mental state reflects that individual's overall positive or negative evaluation of performing a particular behavior. Attitude arises from a set of more specific, salient, behavioral beliefs that reflect perceived outcomes associated with the targeted behavior. Behavioral beliefs indicate individuals' understanding of the consequences from a particular behavior [KIM et al. 2013]. Attitude represents an individual's evaluation of the perceived benefits and drawbacks of adopting a given behavior (e.g. "... be good/bad") [BoudREAU, GODIN 2009].

Attitudes towards performing some acts do not always culminate in this behavior. Perceived behavioral control is partly, but not absolutely, related to actual behavioral control [ARMITAGE, CONNER 2001], which in turn affects the extent to which attitudes are associated with the corresponding behaviors. Perceived and actual behavioral control can sometimes diverge, such as when individuals are oblivious to factors that obstruct or facilitate the indented behavior [Moss 2016].

\section{Subjective norm and normative beliefs}

Subjective norm is defined as "the perceived social pressure to perform or not to perform the behavior [KIM et al. 2013]. In other words, a subjective norm is the recognizable opinions of others who are close to and important to an individual and who maintain influence over decision-making, which affects an individual's behavior to perform or not to perform an action [AJZEN 1991; AJZEN, FISHBEIN 1980; KIM et al. 2013]. Subjective norm reflects the perceived expectations of specific individuals or groups regarding the adoption of a given behavior (e.g. "In your opinion, are the people who are most important to you in favor or not in favor of your regular participation in one or more physical activities in your free time during the next month?") [BOUDREAU, GODIN 2009].

\section{Perceived behavioral control and control beliefs}

The third determinant factor for behavioral attitudeis perceived behavioral control which is described as "the perceived ease or difficulty of performing the behavior" [AJZEN 1991]. That is, the TPB focuses on perceived behavioral control, since identifying and measuring the actual resources and opportunities encountered when performing a particular behavior is difficult [KIM et al. 2013]. Perceived behavioral control is determined by the individual's perception of the presence or absence of resources and opportunities, as well as perceived obstacles and impediments regarding adoption of the target behavior (e.g. "To me, participating in one or more physical activities in my free time during the next month appears difficult/easy") [BOUDREAU, GODIN 2009].

Perceived behavioral control comprises two main facets. First, perceived behavioral control depends on the degree to which individuals conceptualize themselves as sufficiently knowledgeable, skilful, disci- plined, and able to perform some acts, called internal control [KRAFT et al. 2005], which overlaps with the concept of self-efficacy. Second, perceived behavioral control depends on the extent to which individuals feel that other factors, such as the cooperation of colleagues, resources, or time constraints, could inhibit or facilitate the behavior, called external control [KRAFT et al. 2005; Moss 2016].

\section{Intentions}

Although human behavior is extremely complex and still remains unpredictable, psychologists are trying to understand the influential factors in the process of forming intentions and performing behaviors. The theories of Reasoned Action and Planned Behavior are comprehensive theories that specify a limited number of psychological variables that can influence behavior, namely (a) intention; (b) attitude toward the behavior; (c) subjective norm; (d) perceived behavioral control; and (e) behavioral, normative and control belief (FISHBEIN et al. 1992]. In the theory of reasoned action, intention is influenced by the people's attitude toward performing the behavior and the subjective norm. However, the level of perceived control is believed to be influential on people's behavioral intention along with their attitude and subjective norms, according to the theory of planned behavior. Not surprisingly, in most studies, intention is driven by attitudes to a greater extent than by subjective norms [EAGLY, CHAIKEN 1993].

\section{PURPOSE OF THIS STUDY}

The aim of the present study was twofold: to identify the determinants of attitude towards participation in water user association. The following hypotheses were formulated based on Ajzen's theory of planned behavior and earlier research body.

$\mathrm{H} 1$ = there is a significant positive relationship between attitude, subjective norm, Intentions and perceived behavioral control.

$\mathrm{H} 2$ = there is a significant positive relationship between the farmers' Intentions toward participation in WUA and age of farmers.

$\mathrm{H} 3$ = there is a significant positive relationship between the literacy level of farmers and the farmers' Intentions toward participation in WUA.

$\mathrm{H} 4$ = there is a significant positive relationship between farmers' Intentions toward participation in WUA and extension training courses related to the importance of participation in the water management.

\section{MATERIALS AND METHODS}

This study was carried out in Lorestan province, West of Iran. In the whole Lorestan province, there are 24 agriculture water pumping stations. But, only 21 stations were active at the time of this research. A applied study doing by survey methodology. The statistical population consisted of all beneficiaries from agricultural water pumping stations $(N=1990)$ 
in the Lorestan province. Sample size 133 farmer were selected by using Cochran formula. The sampling method was a multi-stage research.

I. Sampling: Sampling was held in three stages.

Step 1: in the first stage of sampling, based on assessments of the experts made by the respective organizations, the beneficiaries were divided into three types of participation in terms of water resources management: weak, medium and strong.

Step 2: in each category, the number of operators have been chosen in proportion to the total number.

Step 3: in the last step, a number of operators were randomly selected (Tab. 1 and Tab. 2).

Table 1. Categories the participation of beneficiaries

\begin{tabular}{|l|c|c|c|}
\hline \multirow{2}{*}{\multicolumn{1}{|c|}{ Specification }} & \multicolumn{3}{|c|}{ Type participation of beneficiaries } \\
\cline { 2 - 4 } & week & medium & strong \\
\hline Number of stations & 5 & 9 & 4 \\
\hline $\begin{array}{l}\text { The number of station } \\
\text { the selected }\end{array}$ & 3 & 4 & 1 \\
\hline
\end{tabular}

Source: own study.

Table 2. Sampling quota

\begin{tabular}{|c|c|c|c|c|c|c|}
\hline County & 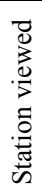 & 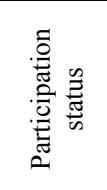 & 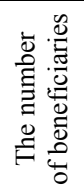 & 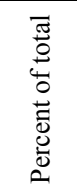 & 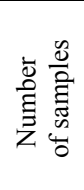 & 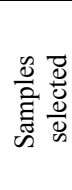 \\
\hline \begin{tabular}{|l} 
Chegini \\
\end{tabular} & 1 & medium & 123 & 13.21 & 17.56 & 18 \\
\hline \begin{tabular}{|l} 
Aleshtar \\
\end{tabular} & 2 & week & 231 & 24.81 & 32.99 & 33 \\
\hline \begin{tabular}{|l|} 
Poldokhtar \\
\end{tabular} & 1 & medium & 94 & 10.09 & 13.41 & 13 \\
\hline \begin{tabular}{|l|} 
Mamolan \\
\end{tabular} & 1 & medium & 88 & 9.54 & 12.68 & 13 \\
\hline \begin{tabular}{|l|} 
Norabad \\
\end{tabular} & 1 & week & 100 & 10.74 & 14.28 & 14 \\
\hline Biranshahr & 1 & strong & 175 & 18.79 & 24.99 & 25 \\
\hline Khoramabad & 1 & medium & 120 & 12.88 & 17.13 & 17 \\
\hline \begin{tabular}{|l} 
Total \\
\end{tabular} & 8 & - & 931 & 100 & 133 & 133 \\
\hline
\end{tabular}

Source: own study.

II. Data collection: The data collection instrument for this research was a questionnaire. The validity of the questionnaire was confirmed by a panel of experts; Cronbach's alpha to test reliability of the measurement scales ranging from 0.83 to 0.91 (Tab. 3).

Table 3. Cranach's alpha coefficients for research variables

\begin{tabular}{|l|c|c|c|c|}
\hline Variable & Mean & $S D$ & $\begin{array}{c}\text { Number } \\
\text { of items }\end{array}$ & $\begin{array}{c}\text { Cron- } \\
\text { bach's } \\
\text { alpha }\end{array}$ \\
\hline$A T T$ & 4.4 & 1.33 & 5 & 0.83 \\
\hline$S N$ & 3.5 & 0.59 & 5 & 0.86 \\
\hline$P B C$ & 3.5 & 0.59 & 4 & 0.91 \\
\hline$I N$ & 2.5 & 0.92 & 5 & 0.84 \\
\hline
\end{tabular}

Explanations: $A T T=$ attitude, $S N=$ subjective norm, $P B C=$ perceived behavioral control, $I N=$ intention, $S D=$ standard deviation. Source: own study.

One section of the questionnaire contained general demographic information such as personal characteristics (5 items), characteristics of lands (4 items), the features related to the water management ( 7 items). The next section was designed to describe farmers' attitudes towards participation in WUAs (5 items), subjective norms ( 5 items), perceived behavioral control (5 items), attitudes (4 items) and perceived behavioral control (4 items). Items were rated on a five point Likert-type scale.

Data was analysed using descriptive statistics including frequencies, percentage, mean rank, and correlation for inferential analysis.

\section{RESULTS}

\section{DESCRIBES THE CHARACTERISTICS OF INDIVIDUAL BENEFICIARIES}

The results showed that the average work experience of farming beneficiaries was 30.22 years which reflects the long history of agriculture; the reason may be that the population is middle-aged, because the average age of farmers was about 49.86 years and the majority of farmers were in the age group of 40 to 50 years old. The results of this research demonstrated that $67.6 \%$ of studied beneficiaries were educated to lower level than high school; it represents that farmers were mostly illiterate. On the contrary, these people had educated families. The results also revealed that despite the large number of family members of farmers (an average of 4 members), the average number of literate family members was 3.45 which represents that families of studied cases were literate; it is the possible reason to explain importance of the education for administrators who wished to have their children continue their education.

Information was related to land ownership, and it represents the scattered distribution of lands in the study area and the dispersion probably has its roots in land distribution before the revolution or inheritance because the lowest ownership of lands was related to the number of lands as 1 and most of them were 9 pieces. In addition to the distribution of land in the study area, the results indicated improper ownership situation in the dry lands, irrigated lands, and gardens since, according to the obtained data, $75.22 \%$ of beneficiaries had less than 3 hectares of dry land, $66.4 \%$ had less than 3 hectares of irrigated lands and the majority $(57.5 \%)$ had no garden which was probably due to water shortage and lack of access to sufficient water resources or financial situation of the subjects.

Construction of the station means that all covered land must be equipped with modern irrigation systems and it needs shaving enabling environment, including educational classes and lending and other related issues. According to the information obtained from the majority of farmers $(80.5 \%)$, they used state funds to improve their irrigation systems but $19.5 \%$ didn't use interests of government credits to improve their irrigation systems. This is may be due to the lack of implementation of the banks commitments made granting loans to subscribers, or because of the difficult financial situation of beneficiaries for payments that leads to this result. Hence now in the $37.9 \%$ of study areas, the traditional irrigation techniques are used. Of 
course, lack of awareness in the participants to the importance of modern irrigation practices and lack of holding training classes both can be the causes of the above issue, because the company's change range, the number of training courses related to sustainable management of water resources in the study area, is between 0 and 2, and an average of 1.72 and the majority of farmers $(60.16 \%)$ had not participated in the training courses related to sustainable management of water resources that is due to the hypothyroidism of the organization responsible for the holding classes. They were not members of any associations. In order to compare and classify the main variables of the study, coefficient of variance for each variable was calculated. Farmers have a high mean score for behavior and attitude towards establishing WUAs.

\section{CORRELATION BETWEEN}

\section{THE MAIN VARIABLES (HYPOTHESIS H1)}

Table 4 shows the results of correlation analysis between the main variables of the study. Table 4 shows that:

- there is positive and significant relationship between major variable of this research;

- the results confirm hypothesis number 1 .

Table 4. The correlation coefficients matrix between variables

\begin{tabular}{|l|c|c|c|c|}
\hline Variables & $A T T$ & $S N$ & $P B C$ & $I N$ \\
\hline$A T T$ & 1 & $0.021^{*}$ & $0.011^{*}$ & $0.00^{* *}$ \\
\hline$S N$ & $0.044^{*}$ & 1 & $0.00^{* *}$ & $0.01^{* *}$ \\
\hline$P B C$ & $0.023^{*}$ & $0.032^{*}$ & 1 & $0.043^{*}$ \\
\hline$I N$ & $0.017^{*}$ & $0.003^{* *}$ & $0.021^{*}$ & 1 \\
\hline
\end{tabular}

Explanations: $A T T=$ attitude, $S N=$ subjective norm, $P B C=$ perceived behavioral control, $I N=$ intention; * significant at $p<0.05$, ** significant at $p<0.01$.

Source: own study.

Correlation between demographic characteristics with attitudes, subjective norm, perceived behavioral control and attitudes (Hypothesis H2, H3 and H4).

Table 5 shows the results of correlation analysis between some important demographic characteristics with attitude, subjective norm, perceived behavioral control and attitudes. Table 5 shows that:

- there are positive and significant, through $1 \%$, relationships between educational level of farmer with attitude, subjective norm, intention and perceived behavioral control;

- there is positive and significant, through $1 \%$, relationship between age and perceived behavioral control;

- also there is positive and significant, through 5\%, relationship between educational and primitive classes of importance of participating in water resources management with attitude, subjective norm, perceived behavioral control and intention;

- results of these researches showed that hypotheses number 2 and 3 were not confirmed.
Table 5. Correlation matrix between demographic characteristics with: $A T T, S N, P B C, I N$

\begin{tabular}{|l|c|c|c|c|}
\hline \multicolumn{1}{|c|}{ Variable } & $A T T$ & $\mathrm{SN}$ & $P B C$ & $\mathrm{IN}$ \\
\hline Age & 0.587 & 0.587 & $0.019 * *$ & 0.494 \\
\hline Family literacy & 0.745 & 0.745 & 0.348 & 0.176 \\
\hline $\begin{array}{l}\text { Educational level } \\
\text { of farmer }\end{array}$ & $0.004 * *$ & $0.004 * *$ & $0.001 * *$ & $0.023 * *$ \\
\hline $\begin{array}{l}\text { Extension training } \\
\text { courses related to the } \\
\text { importance of par- } \\
\text { ticipation in the man- } \\
\text { agement of water }\end{array}$ & $0.026 *$ & $0.032 *$ & $0.021 *$ & $0.042 *$ \\
\hline
\end{tabular}

Explanations: $A T T=$ attitude, $S N=$ subjective norm, $P B C=$ perceived behavioral control, $I N=$ intention; * significant at $p<0.05$, $* *$ significant at $p<0.01$.

Source: own study.

\section{RESULTS OF HYPOTHESES}

Table 6 shows that the hypotheses No. 1 and 4 were confirmed and only hypotheses No. 2 and 3 were rejected.

Table 6. Result of the approval

\begin{tabular}{|l|l|l|l|}
\hline \multicolumn{2}{|c|}{ Hypothesis } & \multicolumn{2}{c|}{ Result } \\
\cline { 2 - 4 } H1 & $\begin{array}{l}\text { There are significant positive relation- } \\
\text { ships between. Attitude, subjective norm, } \\
\text { intention and perceived behavioral con- } \\
\text { trol }\end{array}$ & & \\
\hline H2 & $\begin{array}{l}\text { there is a significant positive relationship } \\
\text { between the intention of participation and } \\
\text { farmers' age }\end{array}$ & & \\
\hline H3 & $\begin{array}{l}\text { there is a significant positive relationship } \\
\text { between the literacy level of farmers' and } \\
\text { the intention to participate in Water User } \\
\text { Association (WUA) }\end{array}$ & & \\
\hline H4 & $\begin{array}{l}\text { there is a significant positive relationship } \\
\text { between farmers' intentions toward par- } \\
\text { ticipation in WUA and extension training } \\
\text { courses related to the importance of par- } \\
\text { ticipation in the management of water }\end{array}$ & & \\
\hline
\end{tabular}

Source: own study.

To continue this part of research, for variables that affect farmers' Intentions towards participation in Water User Association, a step-by-step regression was used. This analysis of regression has been done among all of the variables that have positive and significant relationship. Here, the option of destination has been supposed as dependent variable and the other research option as independent variable.

Table 7. Variables that affect farmers' intentions towards participation in Water User Association

\begin{tabular}{|l|c|c|c|}
\hline \multicolumn{1}{|c|}{ Variable } & Adjusted $R^{2}$ & $R^{2}$ & Sig \\
\hline Subjective norm & 20.00 & 20.20 & $0.001^{* *}$ \\
\hline Attitude & 31.13 & 32.21 & $0.002^{* *}$ \\
\hline $\begin{array}{l}\text { Extension training courses relat- } \\
\text { ed to the importance of participa- } \\
\text { tion in the management of water }\end{array}$ & 42.01 & 42.09 & $0.001^{* *}$ \\
\hline Perceived behavioral control & 49.00 & 49.09 & $0.032^{*}$ \\
\hline Educational level of farmer & 53.00 & 53.90 & $0.001^{* *}$ \\
\hline
\end{tabular}

* Significant at $p<0.05, * *$ significant at $p<0.01$.

Source: own study. 
The results revealed that there were effective variables including subjective norm, attitude, and extension training courses which contributed to the importance of participation in the water management, perceived behavioral control and educational level of farmer was a controlled variable that could affect farmers' attitudes towards participating in Water User Association; these factors could explain 53\% of farmers' participation totally (Tab. 7, Fig. 1).

\section{DISCUSSION}

Human behavior is guided by three kinds of consideration, "behavioral beliefs", "normative beliefs", and "control beliefs". In their respective aggregates, "behavioral beliefs" produce a favorable or unfavorable "attitude toward the behavior"; "normative beliefs" result in "subjective norm"; and "control beliefs" gives rise to "perceived behavioral control". In combination, "attitude toward the behavior", "subjective norm" and "perceived behavioral control" lead to the formation of a "behavioral intention" [AJZEN 2002]. In particular, "perceived behavioral control" is presumed to not only affect actual behavior directly, but also affect it indirectly through behavioral intention [NOAR, ZIMMERMAN 2005].

As a general rule, the more favorable the attitude toward behavior and subjective norm, and the greater the perceived behavioral control, the stronger the person's intention to perform the behavior in question should be. Finally, given a sufficient degree of actual control over the behavior, people are expected to carry out their intentions when the opportunity arises [AJZEN 2002]. According to the results of this research, The results revealed that there were effective variables including subjective norm, attitude, and extension training courses which contributed to the importance of participation in the water management, perceived behavioral control and educational level of farmer was a controlled variable that could affect farmers' attitudes towards participating in Water User Association; these factors could explain 53\% of farmers' participation totally, the following are suggested.

Subjective norms include social elements that are person's beliefs about other people mindset in the field of their actions. In other words, subjective norms variable reflects social influence and pressure that person feels and perceives for doing something (behavior); this means that person pays attention to her/his behavior and the extent to which he will be reprimanded or confirmed by the people or special groups. In fact, these people or groups have a role of guidance reference on behavior that may be father and mother, close friend, colleague etc. As the results of this research showed, the most effective factor on participating Intentions of agriculturists/farmers for participation in WUA is their subjective norms. Thus, in the matter of educational and extensional that is held by proponents, farmers should pay attention to values and norms of that region and the area that are their under-cover. It is necessary besides that all programs that are allocated to farmers pay special attention to families who are the prominent people. This matter causes that act of participation establishes as a value between villagers. One of the methods that could probably be effective is education for children in order for the act of participating are established as value and norm for long-term. By so doing, people who are affected by society's norms will take participating activities seriously and not under coercion for shortterm gains.

The results showed that participating in extension educational courses on the importance of collaboration in water resources management will get the farmers to cooperate in the WUA. This can be prioritized in promulgation programs. It is suggested that agricultural promulgators include such matters as the latest issues, discussions on the importance of agricultural

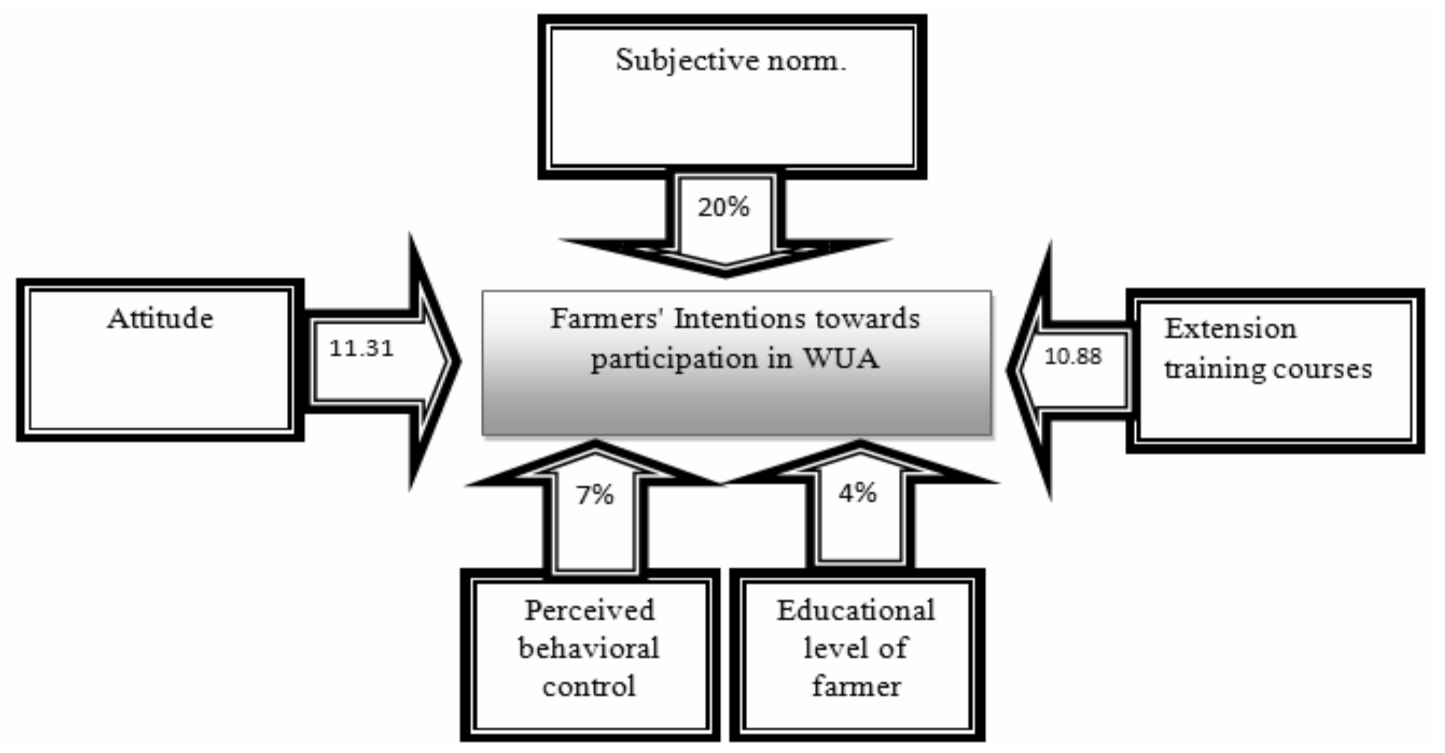

Fig. 1. Variables that affect farmers' Intentions to participation in Water User Association; source: own elaboration 
water resources, and topics that can have a positive effect on farmers' attitudes in the course schedule.

Agricultural promulgators need to speak the local language in order to give the farmers a crystal-clear idea of the contents to make the training more efficient. Whenever possible, through training courses, we would boost the farmers' intention to participate in the WUA.

\section{CONCLUSIONS}

Farmer participation plays an important role in water resource management. Water user association can be a factor in the participation of people in this field. To achieve participation, identification of the behavior of the audience is effective in this field, the results showed that the variables of attitude, subjective norm, intention with the farmers, participation in the Water user association, there are a positive and significant correlation. Perhaps attitude can be effective on the intentions of individuals to participation. And also the attitude causes the subject norm improvement. On the other hand, factors such as the literacy level of farmers, extension training courses have positive effect in audience participation directly. So, it seems that short-term actions, such as extension educational programs about "The importance of water resources", "Water resource management" and "Principles and practices of team working and cooperation" can be effective in audiences' participation. Persuading the farmers to create other rural established it can be effective in attitude, intent and subjective norm and then it will to improve the participation of farmers in the forum. According to the positive correlation between literacy level and participation of audiences, perhaps formal education especially for rural teen and youth can causes participation of future farmers.

\section{REFERENCES}

AFSHAR Z., ZARAFSHANI K. 2008. Analysis desire for partnership in irrigation management (case study leaves and white water user cooperatives cease Sarab in Kermanshah Province). Agricultural Extension and Education. No. 0.6 p. 99-113 (in Persian).

AFSHAR N., ZARAFSHANI K. 2010. An analysis of the tendency toward participating in water management: A case study of water users associations in the cities of Sefidbarg and Sarabbas, Kermanshah, Iran. The Iranian Journal of Agricultural Extension and Education. Vol. 2 p. $99-113$.

AgHAPOUR SABBAGHI M. 2009. Investigating effective factors on adoption of public water association (case study: Getund). The first national conference of modern public participation in study, construction and maintenance of irrigation and drainage networks. $7^{\text {th }}$ and $8^{\text {th }}$ of Jan. Shiraz. I. R. Iran.

AJZEN I. 1991. The theory of planned behavior. Organizational Behavior and Human Decision Processes. Vol. 50(2) p. 179-211.

AJZEN I. 2002. Perceived behavioral control, self-efficacy, locus of control, and the theory of planned behavior.
Journal of Applied Social Psychology. Vol. 32 p. 665683.

AJZEN I., FISHBEIN M. 1980. Understanding attitudes and predicting social behavior. Englewood Cliffs, NJ. Prentice-Hall. ISBN 978-0-13-936435-8 pp. 278.

ARmitage C.J., ConNer M. 2001. Efficacy of the theory of planned behaviour: ameta-analytic review. The British Journal of Social Psychology/The British Psychological Society. Vol. 40 p. 471-499.

Berger T., Birner R., D'iaz J., McCarth N., Wittmer H. 2007. Capturing the complexity of water uses and water users within a multi-agent framework. Water Resource Management. Vol. 21 p. 129-148.

Boudreau F., Godin G. 2009. Understanding physical activity attitudes among French Canadians with type diabetes: an extension of Ajzen's theory of planned behavior. International Journal of Behavioral Nutrition and Physical Activity. Vol. 6:35. DOI 10.1186/1479-58686-35.

Eagly A.H., Chaiken S. 1993. The psychology of attitudes. Michigan. Harcourt Brace Jovanovich College Publishers. ISBN 0155000977 pp. 794.

FAO 2008. Water Report 34 [online]. [Access 16.03.2017]. Available at: http://www.fao.org/nr/water/aquastat/ countries_regions/irn/index.stm

FISHBEIN M., AJZEN I. 1975. Belief, attitude, intention and behavior: An introduction to theory and research. Boston. Addison-Wesley Pub. Co. ISBN 0201020890 pp. 578.

Fishbein M., BANDURA A., TRiandis H.C., KANFER F.H., BeCKeR M.H., MiddLESTADT S.E. 1992. Factors influencing behavior and behavior change. (Report prepared for the National Institute of Mental Health). Bethesda, MD. National Institute of Mental Health p. 3-17.

Hayati D., Ebrahimi E., Rezaee Moghadam K. 2010. The economic advantages of increasing people's participation in developing watering channels and drainage: A case study of Amir Gulf, Fars, Iran. Economy and Agricultural Extension. Vol. 24(3) p. 371-383.

Huang Q., Wang J., Easter K.W., Rozelle S. 2010. Empirical assessment of water management institutions in northern China. Agricultural Water Management. Vol. 98 p. 361-369.

Iran Daily 2015. Iran's agriculture sector uses $92 \%$ of water resoutces [online]. [Access 29.06.2017]. Available at: http://www.iran-daily.com/News/121143.html

Jingling L., Yun L., LiYaA S., ZhiguoA C., BaOdiang Z. 2010. Public participation in water resources management of Haihe river basin, China: the analysis and evaluation of status quo. Procedia Environmental Sciences. Vol. 2 p. $1750-1758$.

Kazbekov J., Abdullaev I., Manthrithilake H., QureSHI A., JuMABOEV K. 2009. Evaluating planning and delivery performance of water user associations (WUAs) in Osh Province, Kyrgyzstan. Agricultural Water Management. Vol. 96 p. 1259-1267.

Kim E., SunNY H., YANG I.S., GIL J.Ch. 2013. The roles of attitude, subjective norm, and perceived behavioral control in the formation of consumers' behavioral attitudes to read menu labels in the restaurant industry. International Journal of Hospitality Management. Vol. 35 p. 203-213.

Kraft P., Rise J., Sutton S., Roysamb E. 2005. Perceived difficulty in the theory of planned behaviour: Perceived behavioural control or affective attitude. British Journal of Social Psychology. Vol. 44 p. 479-496. 
Moss S. 2016. Overview theory of planned behavior [online]. [Access 29.06.2017]. Available at: http://www. sicotests.com/psyarticle.asp?id $=69$

NeJAT Pour H. 2008. Optimal use of water resources using low-irrigation techniques (case study, Fars province). Reporting Journal. Vol. 3(17) p. 37-43.

NOAR S.M., ZIMMERMAN R.S. 2005. Health behavior theory and cumulative knowledge regarding health behaviors: are we moving in the right direction? Health education research. Vol. 20(3) p. 275-290.

QiaO G., ZhaO L., KLEIN K.K. 2009. Water user associations in Inner Mongolia: factors that influence farmers to join. Agricultural Water Management. Vol. 96 p. $822-830$.
Shabanali Fami H., Iravani H., Zarei Z., Mokhtari A. 2008. Challenges and necessities of applying participatory approaches and mechanisms to agricultural water management. The $4^{\text {th }}$ Asian Regional Conference and 10th International Seminar on Participatory Irrigation Management. Tehran, Iran, 2-5.05.2007 p. 165-176.

Tohidyan Far S., Rezaei Moghaddam K. 2015. Attitudes of farmers toward participation in irrigation and drainage projects: the structural equations modeling analysis. Iran Agricultural Research. Vol. 34(1) p. 80-91.

UYSAL Ö., ATIS K.E. 2010. Assessing the performance of participatory irrigation management over time: A case study from Turkey. Agricultural Water Management. Vol. 97(7) p. 1017-1025.

\section{Saeed GHOLAMREZAI, Fatemeh SEPAHVAND}

\section{Udział rolników w Stowarzyszeniu Użytkowników Wody w zachodnim Iranie}

\section{STRESZCZENIE}

Zużycie wody w sektorze rolniczym w warunkach jej deficytu stanowi główne wyzwanie. Konieczna jest zatem optymalizacja zużycia wody i właściwe gospodarowanie wodą w rolnictwie. Wdrożenie partycypacyjnego gospodarowania zasobami wody na obszarach wiejskich i tworzenie stowarzyszeń użytkowników wody może przynieść korzystne efekty. Wymaga to ciagłości gospodarowania, wszechstronnego udziału rolników i eksploatacji zasobów wody. Takie działanie wymaga jednak zrozumienia czynników wpływających na zachowanie konsumentów. Ważna jest więc identyfikacja czynników, które powodują zaangażowanie rolników w stowarzyszeniach. Celem tych badań było określenie czynników skłaniających rolników do udziału w stowarzyszeniach użytkowników wody z użyciem teorii planowanego zachowania (TPB). W prowincji Lorestan w Iranie istnieje 21 czynnych stacji pomp. Rolnicy skupieni wokół każdej z tych stacji tworzą Stowarzyszenie Użytkowników Wody. Populacja poddana badaniu obejmowała członków wszystkich stowarzyszeń w zachodnim Iranie $(N=1990)$. Wykorzystując technike proporcjonalnego stratyfikowanego i losowego wyboru, wybrano z tej populacji 133 rolników. Poprawność stosowanej ankiety została potwierdzona przez panel ekspertów. Wiarygodność ankiety obliczana na wstępnym etapie badań dla różnych jej części wynosiła od 0,83 do 0,91 . Uzyskane dane były analizowane za pomocą programu SPSS 20. Wyniki świadczą, że istnieją efektywne czynniki, takie jak subiektywne normy, nastawienie czy poszerzone szkolenia, które zwiększają znaczenie udziału w gospodarce wodnej oraz że poziom wykształcenia rolnika jest decydującym czynnikiem, który wpływa na jego stosunek względem udziału w stowarzyszeniu. Wymienione czynniki objaśniały 53\% udziału rolników w stowarzyszeniach.

Słowa kluczowe: Iran, stowarzyszenia użytkowników wody, TPB, zamiary, zarzadzanie zasobami wodnymi 